\title{
ESTETIKA TARI SRIMPI RANGGA JANUR PADA MASA SRI SULTAN HAMENGKU BUWONO VIII DI KRATON YOGYAKARTA
}

\author{
Rahma Indrasari \\ Jurusan Seni Tari Fakultas Seni Pertunjukan ISI Yogyakarta \\ email: indrasari431@gmail.com
}

\begin{abstract}
RINGKASAN
Srimpi atau Serimpi merupakan suatu komposisi tari putri gaya Yogyakarta yang pada umumnya didukung oleh empat orang penari. Srimpi Rangga Janur merupakan tari klasik gaya Yogyakarta yang terdapat pada Manuskrip mulai masa Sri Sultan Hamengku Buwono VII. Penelitian ini dilakukan untuk mengetahui, mengungkap, dan mendeskripsikan estetika tari Srimpi Rangga Janur pada masa Sri Sultan Hamengku Buwono VIII. Metode penelitian menggunakan metode kualitatif dengan pendekatan estetika. Teknik pengumpulan data dilakukan dengan observasi, wawancara, dan studi dokumen. Teknik analisis data menggunakan analisis kualitatif. Kredibilitas data dilakukan dengan triangulasi metode dan triangulasi sumber. Hasil penelitian menunjukkan bahwa estetika tari Srimpi Rangga Janur dapat diketahui melalui: unity (keutuhan) jika dikaitkan dengan konsep Jawa tentang sêlirang sêtangkêp dan loro-loroning atunggal. Variety (variasi) dapat disejajarkan dengan wilêd dalam Hasta Sawanda. Repetisi (pengulangan) dapat diketahui dari perhitungan beberapa motif yang sering diulang. Contrast (kontras) dapat diketahui dari motif gerak yang berlawanan. Transtition (transisi) dapat disejajarkan dengan pancad dalam Hasta Sawanda. Sequence (urutan) dapat diketahui dari struktur koreografi dan struktur iringan serta dapat diejajarkan dengan konsep mandhêg milir. Climax (klimaks) dapat diketahui dari struktur koreografi dan struktur gendhing. Proportion (proporsi) dapat diketahui dari besar kecilnya kuantitas antara gerak, tempat pertunjukan dan penari. Balance (keseimbangan) dapat dikaitkan dengan konsep Jawa tentang sangkan paraning dumadi (mulih mula mulanira). Harmony (selaras) dapat diketahui dari keselarasan dari gendhing pengiring dengan gerak-gerak yang lembut, runtut, patut, luruh - jêtmika, dengan tata krama, teratur, terkendali, mbanyu mili, serta tempo yang ajêg.
\end{abstract}

Kata kunci: Srimpi, Rangga Janur, Estetika.

\begin{abstract}
Srimpi or serimpi is Yogyakarta classical dance composition commonly perform by four dancers. Srimpi Rangga Janur is a Yogyakarta-style classical dance found in manuscripts from the Sri Sultan Hamengku Buwono VII. This research was conducted to determine, uncover and describe the aesthetics of Srimpi Rangga Janur dance.

Method with aesthetic approach was used for this research. The data collecting techniques were observation, interview, and document study. The data analyzing technique was qualitive method. The data credibility proved by triangulation method and triangulation source.

The result of the research showed that the Srimpi Rangga Janur's aesthetics known from: the unity related to the Javanese concept about sêlirang sêtangkêp and loro-loroning atunggal. Variety equal to the wilêd in Hasta Sawanda. Repetition can be known from the calculation several motif which often repeated. Contrast can be known from the opposite movement motif. Transition can be equaled with pancad in Hasta Sawanda. Sequence can be known from the structure of the choreography and the music and can be equaled with mandhêg milir concept. Climax can be known from the structure of the choreography and gendhing. Proportion can be known from the quantity
\end{abstract}


between movement, venue, the dancers. Balance related with the Javanese concept about sangkan paraning dumadi (mulih mula mulanira). Harmony can be known from the gendhing's harmony with the soft, coherent, patut, luruh-jetmika, movement with the manners, organized, controlled, mbayu mili and contantly tempo (ajeg).

Keyword: Srimpi, Rangga Janur, Estetika.

\section{PENDAHULUAN}

Tari klasik gaya Yogyakarta merupakan salah satu kesenian istana yang terikat oleh standarisasi atau aturan-aturan baku, karena terdapat prinsip dan batasan-batasan formal. Adapun pathokan-pathokan tari klasik gaya Yogyakarta ialah sikap dan gerak badan, sikap dan pandangan mata, gerak leher atau pacak gulu, gerak tangan, serta sikap dan gerak dari kaki. Aturan baku, prinsip, dan batasan-batasan tersebut harus ditaati oleh seorang penari baik putra maupun putri untuk mencapai tingkat kepenarian yang optimal.

Salah satu tari istana di Kraton Yogyakarta ialah tari Srimpi. Srimpi atau Serimpi merupakan suatu komposisi tari putri gaya Yogyakarta yang pada umumnya didukung oleh empat orang penari. Akan tetapi, dalam Srimpi tertentu didukung oleh lima orang penari, yaitu Srimpi Renggawati karya pada masa pemerintahan Sri Sultan Hamengku Buwono V di Yogyakarta. Selain itu terdapat istilah Serimpi Lajuran yang merupakan istilah lain dari Bedhaya sebagaimana disebutkan bahwa:
Bedhaya sering disebut dengan istilah Sêrimpi Lajuran. Konsep sêrimpi dan lajur semacam ini seiring dengan konsep budaya Jawa berbunyi curiga manjing warangka yaitu keris yang masuk di dalam sarungnya. Dikatakan demikian karena empat penari yang di luar lajur yang disebut sêrimpi adalah wadahnya, sedangkan lajur yang merupakan penari yang di tengah adalah isinya, sehingga disebut serimpi lajuran. Dengan demikan konsep Serimpi Lajuran atau curiga manjing warangka merupakan loroloroning atunggal, atau satu kesatuan yag tidak terpisahkan. Di samping itu kemungkinan mengandung makna kesuburan, seperti halnya kesetaraan lingga dan yoni (Dinas Kebudayaan DIY, 2009: 315).

Pada sisi lain Srimpi Lajuran atau Bedhaya dengan jumlah pendukung sembilan merupakan simbol angka terbesar, yang berkaitan dengan konsep babahan hawa sanga, yaitu sembilan lubang hawa nafsu yaitu dua 
mata, dua telinga, dua hidung, mulut, alat kelamin, dan dubur. Siapa yang bisa mengendalikannya akan bisa mengatur hidupnya dengan baik. Adapun Srimpi dengan jumlah empat melambangkan kéblat papat atau empat arah mata angin. Titik kardinal adalah ibu mata angin yang menjadi pusat dari empat pokok yaitu utara, selatan, barat, timur. Titik kardinal merupakan titik pijak seseorang bisa menentukan arah mata angin.

Pada saat ini, untuk kepentingan pembelajaran tari Srimpi Rangga Janur yang berdurasi 1 jam sudah dipadatkan menjadi kurang lebih 20 menit. Pada tahun 2014 Taman Budaya Yogyakarta bekerja sama dengan paguyuban seni Kridha Beksa Wirama Yogyakarta merekonstruksi tari Srimpi Rangga Janur yang berdurasi 1 jam. Hasil rekonstruksi dipentaskan di pendapa Ndalem Tejokusuman, Yogyakarta, serta didokumentasikan oleh Taman Budaya Yogyakarta. Secara koreografis tari ini ditarikan oleh 4 orang penari putri yang merupakan penari inti, dan 4 dhudhuk yang membawakan properti berupa jêbêng yang bergambar figur tokoh wayang Srikandhi pada dua jêbêng dan figur tokoh wayang Larasati pada dua jêbêng lainnya.

Tari Srimpi Rangga Janur diiringi instrumen gamelan Jawa. Secara khusus menggunakan instrumen kêmanak yang tidak ada di tari srimpi lainnya. Kêmanak merupakan alat musik gamelan yang berbentuk seperti pisang atau sendok yang memiliki tangkai di bagian ujungnya dan terdapat lubang memanjang di bagian badannya. Instrumen kêmanak dimainkan dengan cara ditabuh dan dipadukan dengan alat musik tradisional lainnya. Kêmanak pada umumnya digunakan untuk mengiringi tari Bedhaya. Akan tetapi pada tari Srimpi Rangga Janur kêmanak digunakan hampir di seluruh pertunjukan, kecuali pada bagian perangan. Instrumen ini memiliki karakter suara pelan atau alus yang dimainkan untuk karakter lagu dengan tempo yang lambat. Instrumen gamelan yang digunakan banyak menggunakan tabuhan pada instrumen depan yang terdiri dari gêndèr barung, gêndèr pênêrus, gambang, slênthêm, sitêr, rêbab. Selain itu, selama proses sajian tari, waranggana melantunkan lirik lagu yang mengisahkan perang antara Srikandhi dan Larasati.

Berbagai keunikan yang terdapat pada tari Srimpi Rangga Janur dikaji dari aspek estetika. Estetika suatu karya tari dapat dikaji dari segi teks dan konteksnya. Secara tekstual, estetika tari Srimpi Rangga Janur akan meliputi sepuluh aspek. Kesepuluh aspek tersebut yaitu unity (kesatuan) variety (variasi), repetition (pengulangan), contrast (kontras), transition (transisi), sequence (urutan), climax (klimaks), proportion (proporsi), harmony (harmoni), balance (keseimbangan). Prinsip-prinsip tersebut terdapat pada buku Elizabeth R Hayes 


\section{JOGED}

ISSN: $1858-3989$

yang berjudul Dance Compotition and Production. Akan tetapi bahwa kesepuluh prinsip-prinsip tersebut di dalam tari Jawa memiliki konteks yang berbeda dengan cara pandang Barat. Maka untuk menganalisis tari Srimpi Rangga Janur prinsip estetika Hayes hanya akan dipinjam untuk mengkategorisasikan. Sedangkan pembahasannya akan disesuaikan oleh pandangan Jawa. Konsep Jawa yang dimaksud antara lain: sêlirang sêtangkêp, mandhêg milir, loro-loroning atunggal, sangkan paraning dumadi (mulih mula mulanira).Dari paparan di atas dapat dirumuskan masalah sebagai berikut: Bagaimana estetika tari Srimpi Rangga Janur Gaya Yogyakarta pada masa Sri Sultan Hamengku Buwono VIII?

Metode penelitian menggunakan metode kualitatif dengan pendekatan estetika. Teknik pengumpulan data dilakukan dengan observasi, wawancara, dan studi dokumen. Teknik analisis data menggunakan analisis kualitatif. Kredibilitas data dilakukan dengan triangulasi metode dan triangulasi sumber.

\section{PEMBAHASAN}

\section{A. Latar Belakang Historis}

Naskah tari Srimpi Rangga Janur yang tersimpan di perpustakaan KHP Kridha Mardawa Kraton Yogyakarta dengan kode manuskrip B/S 11 dan B/S 12, ditemukan pada zaman Sri Sultan Hamengku Buwono VII.
ESTETIKA TARI SRIMPI RANGGA JANUR PADA MASA SRI SULTAN HAMENGKU BUWONO VIII DI KRATON YOGYAKARTA

Sultan Hamengku Buwono VII lahir pada 4 Februari 1839 dengan nama G.R.M Murtedjo yang naik tahta pada tahun 1877. Sri Sultan Hamengku Buwono VII mempunyai 21 istri serta mempunyai 78 anak yang terdiri atas 31 anak laki-laki dan 47 anak perempuan. Pada tahun 1872 - 1883, G.K.R. Kencono merupakan permaisuri Sultan yang harus dilengserkan dan gelar menjadi G.K.R. Wandhan (Safitri, 2019: 50). Kemudian, kedudukan permaisuri digantikan oleh G.K.R. Hemas yang memiliki lima anak laki-laki dan enam anak perempuan. Putra laki-laki pertama bernama G.R.M. Akhadiyat ketika umur sembilan tahun diangkat menjadi putera mahkota (Margana, 2016: 43). Pada tahun 1892, G.K.R. Hemas wafat, dan setahun kemudian sang putra mahkota masih berusia 17 tahun juga wafat. Sri Sultan Hamengku Buwono VII kemudian mengangkat G.R.M. Pratistha sebagai pengganti G.R.M. Akhadiyat, yang bergelar Adipati Juminah. Akan tetapi gelarnya dicabut karena kesehatannya. Kemudian yang ketiga kali posisi putera mahkota jatuh kepada G.R.M. Putro, akan tetapi putera mahkota meninggal karena sakit keras. Akhirnya G.P.H. Puruboyo diangkat sebagai putra mahkota. Setelah G.P.H. Puruboyo setuju untuk menggantikan ayahanda, kemudian Sri Sultan Hamengku Buwono VII memutuskan untuk lèrèh kêprabon (turun tahta) dan beristirahat di 
ESTETIKA TARI SRIMPI RANGGA JANUR

PADA MASA SRI SULTAN HAMENGKU BUWONO VIII DI KRATON YOGYAKARTA

Pêsanggrahan Ambarukmo. Pada tanggal 8

Februari 1921, G.P.H. Puruboyo kemudian dinobatkan sebagai Sri Sultan Hamengku Buwono VIII.

Pada manuskrip B/S 11 berisi Kagungan Dalêm Sêrat Pasindhèn H.B VII. Manuskrip tersebut berisi Sêrat Pasindhèn untuk 20 Bedhaya dan 16 Srimpi. Pada daftar terdapat 34 terdaftar akan tetapi pada nomor 31 kosong. Sesudah nomor 34 masih terdapat Srimpi dan 1 Bedhaya lain yang tidak dimasukkan dalam daftar. Pada manuskrip tersebut terdapat Halaman: kosong + daftar i/ii (iii/iv kosong); + $1-284+5$ kosong. Ukuran manuskrip B/S 11 ialah 22.5 x 34; dalam 21,5 x 34. Adapun isi dari Sêrat Pasindhèn pada Manuskrip tersebut ialah:

Srimpi Rangga Janur.

Srigra Mangsah, Sri Putri Cêmpalarêja tilar parê... Kanira cêthi gya tumandhuk samya ayu, wananira sri putri kalih.

Kaé, Hênggé, Yandho

Gya tumimbang sri rêtna yularas satya. Dhapo yudo sawadyoné, para cêthi tampuh ing prang kapranggul samya wanodya. Kahé, hênggé, yandho. Atandhing samya putri ayu hutama. Kadya kêmbar sri putri cêmpala lancah rêtna yularasatya samya kuntap. Kaé, hênggé, yandho. sarubawor tambuh mungsuh lawan rowang, suwaraning warastra anglêr. Jawoh curi gatarung samya curiga. Kaé, hênggé, yandho. caruk rukêt kang bala samya wanodya watang tuna, acaruk Kris ting carêngkling. Tanpa parung.. sambaté pra dyah kabranan. Kaé, hênggé, yandho. Dyah ayu Cêmpala lancah laras satya datan pawor sri dyah lawan balanira. Dadya ngléla sri putri kalih ningrat. Kaé, hênggé, yandho. Kang ngayuda dyah ayu samya utama amantêsi ngasta jêbêng ing ngajurit angciragêng, solah anuting brêdongga. Kaé, hênggé, yandho. Sri dyah dèwi laras satya angandika, boya sira putri ing cêmpalarêja ayu éman mati ngranangur nungkula. Kaé, hênggé, yandho. Sri dyah ayu cêmpala bramantya. Ing ngandika pêksa lancing ujarira balik sira nungkul srah nalakênira. Kaé, hênggé, yandho. Mangu in prang utawi jêbêng wiraga. Anut tinut apagut papan pinapan kawang wang kuliling wènthêr kawêdhar. Kaé, hênggé, yandho. kang ngayuda samya wantêr sru kawêdhar aputêran kadêdêr midêr kadêran pan kasya kuwu tarung kipat kinipat. Kaé, hênggé, yandho. Bawa tanu wijilé sibawataka pilih marga yèn mati aja tansara papag pupug gunandhing prang tanpa sama. Kaé, hênggé, yandho. Dangu ing prang wêwéka kantukan tênan. Sura sêkti kinêkêr kêntar kumintêr. Aprabawa ruwa raga ragurnita. Kaé, hênggé, yandho. Kuwung kuwung ingkang jala dara mêncung yangalimut sincung rieut pracalita. Rugêswang lata karêbah kapala warsa. Kaé, hênggé, yandho. Bayu bajra musus lésus mawa ngrasa. Manah penuh mawêréh jêbêng pinonah lir pawaka sumirat lata rèng nêtya (Kagungan Dalêm Sêrat Pasindhèn Bêdhaya Utawi Srimpi, B/S 11).

Manuskrip tentang Srimpi Rangga Janur pada masa Sri Sultan Hamengku Buwono VIII terdapat beberapa Manuskrip yang di dalamnya terdapat Srimpi Rangga Janur di antaranya B/S 13, B/S 14, B/S 15, B/S 16, B/S 17, B/S 18, B/S 20, B/S 23. Adapun manuskrip diambil dari naskah tertua pada zaman Sri Sultan Hamengku 
JOGED

ISSN: $1858-3989$

Buwono VIII yaitu pada kode B/S 13.

Sebagaimana isi dari Sêrat Kandha Bêdhaya

utawi Srimpi ialah:

Punika lampahipun lêlangên dalêm Srimpi. awit lagon Pathêt Manyura. Sakkèndêlipun lagon tumuntên dipun nyariosakên.

Sebêtbyar wahuta. Hanênggih ingkang dipun nyariosakên punika. Lêlangên Dalêm Srimpi Pasindhèn Pratama Karsa Dalêm Ingkang Sinuhun. Kangjêng Sultan Hamêngku Buwana Senapati Ing Ngalaga Ngabdurrahman Sayidin Panatagama Kalifatullah Ingkang Jumênêng Kaping VIII.

Grut Opvisir Van de Orde Van Oranye Nasao Met Silaver Rênester Opvisir Ring Orde Van Oranya Nasao, Met de Swarden Saha Jendral Mayor Ri Wadyabalanipun Kangjêng Sri Maharaja Putri Ing Nagari Nederlan. Ingkang Sudibya Angrênggani Karaton Karsa Dalêm Ing Ngayukyakarta Hadiningrat. Karsa dalêm amangun susilaning bêksa Srimpi sak kalangkung hamarsudèng karsa pinudya sinukmèng cipta. Kawiragan ambêktyas kawicita. Kawang wang langêning konca riwus kapranèng karpa kawêdharing sukaharja. Wondéné ingkang linupi yèng ing gita. Cariyosipun sarat ringgit purwa nalikaningpun putri adi ing nagari Cêmpalarja. Sang dyah retna dewi wara Srikandhi. Sakdèrèngipun ginarwa sang Dananjaya. Putri kasusra ing pramudita. Kaloka ing jaga. Ayu tur prajurit sudibya ing têmbé prang Bratayuda. Wigya bingkas ingkang satru krêpnadhaswasa sang rêsi Bisma pala swasra madyaning ranangga. Mêlasi sang dyah rêtna sangsaya kongas kawijayanira. Samantara Sang Dyah Dewi Wara Srikandhi sampun adarbé pasang giri. Yèn tan wigya ngraosakên kaprawiranira ing ngayuda. Suka lila tan palakrama marmamangké tinandhing samya
ESTETIKA TARI SRIMPI RANGGA JANUR PADA MASA SRI SULTAN HAMENGKU BUWONO VIII DI KRATON YOGYAKARTA

wanodya sintên ta anênggih garwanira satriya ing Madukara tang ran Sang Dyah Larasati putri adi ing Magada. Putranira mraja Mondrasan. Tinandhing prang tur samya putri ayu utama. Sudibya mbêkmah ambara. Purwanira mangsah kaprajan dhumatêng ingkang raka satriya Arjuna. Sasaniskaranira prakawis sinukmèngkas melaning wardaya. Mila sang Dyah Retna sumêla kêng karpa. Tambuh tambuh raosing galih. Nguntar nguntarké wraning duka. Dadya nuwun pamit ing raka sang Dananjaya. Amêthuk kang pêksa sura. Humangsah ing rananggana. Lajêng bodhol sawadya prajurit wanoddya têkaning pabaratan. Wuswasêmpuk ran mêngsah lajêng sami atata gêlar rinakit mangkara ngyuha Tan kuciwa kalih kalihira.

Sami winong wonging jawata. Wahuta, riwung ramugêng laga. Gya sami têdhak sangking wahananira. Rata kênyana jrog adi ing nagari Cempalarja. Sang Dyah Retna Dewi Wara Sikandhi, sakdèrèngipun ginarwa sang Dananjaya. Putri kasusra pramudita, kaloka ing jaga, ayu tur prajurit sudibya ing tembe prang bratayuda. Wigya bingkas ingkang satru sêksi Dêraka prananing capadibya. Parimin. Mangrêngèng bathara krêpnadhaswasa sang rêsi Bisma, pala swasa madyaning ranangga. Mêlasi Sang Dyah Retna sangsaya kongas kawijayanira. Samantara Sang Dyah Dewi Wara Srikandhi sampun adarbé pasiang giri. Yèn tan wigya ngraosakên kaprawiranira ing ngayuda. Suka lila tan palakrama. Marmamangké tinandhing samya wanodya sintên ta anênggih garwanira satriya Madukara, teng ran Sang Dyah Larasati putri adi ing Magada. Aksara tinandhing yuda ènjèr mentarakên kawiragan ing salira. Dasar putri sami ayu ingkang warna. 
Sumbaga prawireng laga. Lir kembar sanis kaprana ngginggana Kaprabon ing ngayuda. Mawaracitaning rêtna. Mawrung manising saking mandrawa. Lir wulan kêmbar tumimbang kisma. Sarêng pagut pyaking cidya ing galih. Kayogya paralahing sayumbara tansah sami dénrakra sasèrèndanira (Kagungan Dalêm Sêrat Kandha Bêdhaya Utawi Srimpi, B/S 13).

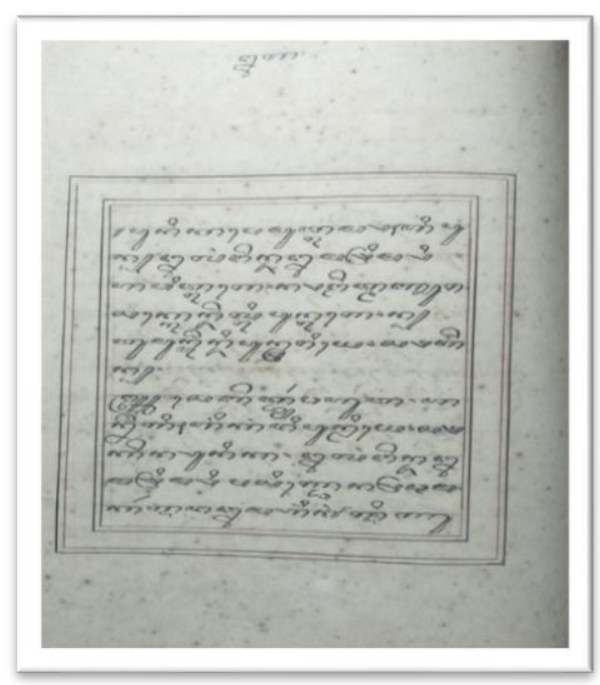

Gambar 1. Foto Manuskrip B/S 13

(Dokumentasi: Rahma, Maret 2020)

Dinyatakan oleh Sri Sultan Hamengku

Buwono X dalam pidato Penganugerahan Gelar Doctor Honoris Causa bidang Seni Pertunjukan di ISI Yogyakarta yang menyatakan bahwa: Setiap karya cipta seni itu punya konteks dengan waktu (Hamengku Buwono X, 2011: 7). Apabila pernyataan tersebut dikaitkan dengan tari Srimpi Rangga Janur pada masa Sri Sultan Hamengku Buwono VII, diasumsikan bahwa tari Srimpi Rangga Janur terkait dengan situasi yang dialami oleh Sri Sultan Hamengkubuwono VII. Berbagai peristiwa tersebut mengindikasikan bahwa kemunculan Srimpi Rangga Janur terkait dengan suasana peristiwa yang terjadi pada waktu itu. Peristiwa yang membutuhkan ketangguhan, ketahanan, keperwiraan, di dalam menghadapi situasi. Selain itu tercatat dua pergelaran wayang wong dengan cerita Sri Suwela dan Pergiwa-Pergiwati (Wibowo, 1981: 46). Cerita Sri Suwela yang mengisahkan tentang istri Bima yang mengubah diri menjadi Prabu Sri Suwela. Cerita Pergiwa-Pergiwati merupakan cerita yang mengisahkan tentang Pergiwa-Pergiwati yang mencari ayahnya. Kedua cerita tersebut mengisahkan tentang kegigihan seorang wanita. Tari Srimpi Rangga Janur yang menceritakan tentang peperangan antara Srikandhi dan Larasati menunjukkan sifat keprajuritan Srikandhi. Dinyatakan dalam sêrat kandha: prajurit sudibya ing têmbé prang Bratayuda. Wigya bingkas ingkang satru krêpnadhaswasa sang rêsi Bisma pala swasra madyaning ranangga (Kagungan Dalêm Sêrat Kandha Bêdhaya Utawi Srimpi, B/S 13). Pernyataan ini menunjukkan bahwa Srikandhi adalah prajurit yang sakti dan sanggup maju ke medan perang sebagai sénapati. Keperwiraan Srikandi tersebut dapat diasumsikan bahwa Sri Sultan Hamengku Buwono VII mengidolakan tokoh Srikandhi sebagai sosok wanita yang tangguh.

\section{B. Estetika Tari Srimpi Rangga Janur} Pada Masa Sri Sultan Hamengku Buwono VIII di Kraton Yogyakarta Hadiningrat 


\section{JOGED}

ISSN: $1858-3989$

Estetika atau aesthetics merupakan sebuah istilah yang secara tradisi telah dipakai untuk menyebut pada salah satu bentuk cabang filsafat yang mengacu dari segi "yang indah" dan "keindahan" daripada alam semesta seni. Istilah ini pertama diperkenalkan oleh filsof Jerman yaitu Alexander Baumgarten, yang hidup seputar tahun 1714 - 1762. Estetika adalah sebuah istilah yang berasal dari Bahasa Yunani yaitu aistetika yang berarti hal-hal yang diserap oleh panca indera; aisthetis berarti penyerapan panca indera (sence of perception). Terdapat istilah kalangwan di Jawa yaitu seni menulis puisi. Kalangwan atau Kalangön yang berarti "keindahan", karena dapat menciptakan dan menikmati karya-karya sastra orang terangkat ke luar dirinya sendiri (ekstasis "langö") dan terhanyut dalam mengalami keindahan (Zoetmulder, 1983). Ekstasis atau ekstasi pada KBBI merupakan tablet yang mengandung zat adiktif dan mampu memacu kekuatan daya tubuh dan menimbulkan perasaan senang, riang, gembira, dan riang terhadap sesuatu. Perasaan senang, riang, gembira, dan riang terhadap sesuatu terkait dengan menikmati objek seni. Seni tari sebagai bagian dari seni pertunjukan diharapkan mampu memunculkan perasaan-perasaan tersebut. Ketika melihat sebuah pertunjukan tari yang di dalamnya termasuk tari tradisi diharapkan perasaan dapat hanyut ke dalam pertunjukan tersebut. Hal tersebut sejalan
ESTETIKA TARI SRIMPI RANGGA JANUR PADA MASA SRI SULTAN HAMENGKU BUWONO VIII DI KRATON YOGYAKARTA

dengan pernyataan Priyono pada buku Mengenal Tari Klasik Gaya Yogyakarta ketika mengkaitkan nama Srimpi ke akar kata "impi" atau mimpi. Menyaksikan tarian lemah gemulai sepanjang $3 / 4$ hingga 1 jam itu sepertinya orang dibawa ke alam lain (Wibowo, 1981: 42). Sebagaimana penonton dapat nyawiji atau menyatu dengan sebuah pertunjukan. Dengan demikian, sebagai penonton akan menjadi bagian dari pertunjukan tersebut.

Gerak merupakan unsur yang utama di dalam tari. Unsur dalam musikal juga penting di dalam sebuah tari yaitu irama dan ritme. Maka dari itu kedudukan musik sangatlah penting bagi sebuah pertunjukan tari. Sebagaimana B.P.H. Suryodiningrat salah seorang tokoh tari gaya Yogyakarta berpendapat bahwa: Ingkang kawastanan jogèd inggih punika ébahing sadaya sarandhuning badan, katata pikantuk wiramaning gêndhing, jumbuhing pasêmon, sarta pikajênging jogèd (Suryodiningrat, 1934: 3). (bahwa yang disebut tari adalah bergeraknya seluruh anggota badan, yang ditata dengan irama gêndhing, ekspresi tari serta maksud dari tariannya), serta berpijak pada kualitas penari yang dapat diketahui dari wiraga, wirama, wirasa. Wirasa yang memuat filsafat joged Mataram yang terdiri dari sawiji, grêgêd, sêngguh, ora mingkuh. Dengan demikian wiraga, wirama, wirasa merupakan satu kesatuan yang tidak dapat dipisahkan untuk mengetahui kualitas penari. Kualitas 
ESTETIKA TARI SRIMPI RANGGA JANUR

PADA MASA SRI SULTAN HAMENGKU BUWONO VIII DI KRATON YOGYAKARTA

yang akan memunculkan keindahan gerak yang dapat berpengaruh pada penonton.

\section{Unity (Kesatuan)}

Dikatakan dalam istilah Jawa sebagai loroloroning atunggil sebagai wujud dari penyatuan atau panunggalan. Pernyataan tersebut menjelaskan bahwa bentuk dan isi merupakan dua fase tetapi menjadi satu dan menjadi hubungan yang bermakna. Bentuk merupakan sesuatu yang terindra yang dapat diketahui pada struktur koreografi, gerak, iringan, dan tempat pertunjukan. Aspek isi dari tari Srimpi Rangga Janur terdapat dari unsur cerita yang diambil dari epos Mahabarata yaitu peperangan antara Srikandhi dan Larasati. Namun demikian karena tari Srimpi bersifat simbolis aspek isi dapat diketahui dari penghayatan para penari di dalam melakukan setiap gerakan.

Tari Srimpi selama ini diketahui berjumlah empat penari, sementara apabila dilakukan dua penari dinamakan Sari Kembar. Meminjam istilah Ben Suharto tentang sêlirang dan sêtangkêp yang menyatakan: Srimpi is a dance performed by two pairs of females. If we equate one pair of dancers to one lirang, a single pair of dancers can be thought of as a whole in itself. With the addition of the other pair, it becomes one tangkêp (Suharto, 1998: 53). (Srimpi merupakan tarian yang dilakukan oleh dua pasang penari. Jika kita menyamakan satu pasang penari menjadi satu lirang (sêlirang),
JOGED

ISSN: $1858-3989$

sepasang penari dapat dianggap sebagai keseluruhan dalam dirinya. Dengan penambahan pasangan lainnya itu menjadi satu tangkêp (sêtangkêp). Dengan demikian apabila Srimpi dilakukan oleh dua penari (sêlirang) yang dinamakan Sari Kembar tetap sebagai bentuk unity. Sementara apabila dilakukan oleh empat penari maka tidak dinamakan dua lirang, akan tetapi setangkêp yang merupakan unity atau tetap utuh.

Tari Srimpi Rangga Janur sebagai salah satu pertunjukan tari di dalamnya terdapat beberapa unsur pembentuk yaitu pola gerak, iringan tari, dan tempat pertunjukan semuanya menjadi bentuk satu kesatuan. Pola gerak merupakan satu kesatuan dari berbagai motif atau ragam gerak yang dibentuk menjadi satu kesatuan bentuk koreografi tari Srimpi Rangga Janur. Antar bagian ragam gerak yang disatukan oleh sêndi sebagai transisi dalam posisi di tempat (stationer movement) dan gerak penghubung (locomotor movement). Motif gerak posisi di tempat (stationer movement) dan gerak penghubung (locomotor movement) keduanya memuat konsep mandhêg milir. Salah satu contoh motif gerak tasikan yang terdapat pada tari Srimpi Rangga Janur, dengan sikap awal dari gerakan yang bertumpu pada dua kaki yang sudah tertentu bentuknya yang biasa dinamakan mapan (Winahyuningsih, 1988: 50). Mapan di dalam gerak tasikan ini akan selalu hadir dalam setiap gerakan mandhêg (di tempat). 


\section{JOGED}

ISSN: $1858-3989$

Sedangkan gerak-gerak milir (berpindah tempat) sebagai salah satu contoh ialah motif ngêndhèrèk. Motif ngêndhèrèk yang dilakukan dalam posisi kaki gêdrug kanan nglèyèk kiri, ngênêti ke belakang, kemudian gêdrug kiri nglèyèk kanan, gêdrug kiri sêblak sampur kanan. Sikap gerak nglèyèk yang diawali dengan posisi mapan (mandhêg) kemudian perpindahan berat badan dari kanan ke kiri dan didahului dengan mêndhak kemudian ingsêt tumit sebagai bentuk gerak milir. Namun pada dasarnya motif-motif yang digunakan mengandung konsep mandhêg milir.

Iringan di dalam tari Srimpi Rangga Janur bukan iringan yang bersifat ilustratif, akan tetapi gendhing yang berpola yaitu bagian jogédan pola gêndhing kêtawang, kicat èrèk dengan pola gêndhing ayak-ayak, dan srêpêg untuk bagian perangan. Pola gêndhing kêtawang yang setiap satu gong terdiri dari 16 hitungan $(2 \times 8)$, selaras dengan ragam-ragam yang digunakan pada tari Srimpi Rangga Janur dengan pola gerak yang setiap ragam gerak terdiri $2 \times 8$ hitungan. Artinya terdapat satu kesatuan antara pola gerak dengan pola gêndhing. Sedangkan instrumen kêmanak berfungsi sebagai pamengku irama atau pamengku lagu (Hendarto, 2006: 47). Dengan demikian bunyi instrumen kêmanak menjadi pembingkai atau pemersatu dalam sajian Srimpi Rangga Janur. Sedangkan pengatur seluruh irama atau pamurba irama dilakukan
ESTETIKA TARI SRIMPI RANGGA JANUR PADA MASA SRI SULTAN HAMENGKU BUWONO VIII DI KRATON YOGYAKARTA

oleh pêngêndhang. Pêngêndhang sebagai pamurba irama, yang membuat cepat lambatnya, pergantian gendhing, dan memulai dan berhentinya iringan menurut aba-aba pêngêrak. Dari fungsi kêprak tersebut, pêngêprak sebagai pengatur pertunjukan yang menyatukan antara pertunjukan dengan iringan. Oleh karena itu seorang pêngêprak diharapkan menguasai aspek tari dan aspek gêndhing.

Ruang pertunjukan yang digunakan sebagai tempat pergelaran tari Srimpi Rangga Janur untuk pendokumentasian pada tahun 2014 yaitu di pendhapa Ndalem Tedjokusuman. Struktur bangunan pendhapa dengan empat saka guru yang berada di tengah menjadi titik pusat atau fokus. Hal tersebut sejalan dengan pernyataan Ronald bahwa: keutamaaan jumlah saka guru adalah empat buah dengan kesan vertikal dan mempunyai suasana pemusatan berada di titik diagonal yang terbentuk oleh keempat titik kedudukan tiap saka guru (Ronald, 2005: 50). Pendhapa sebagai bangunan secara fisik merupakan ruang yang pasif, akan tetapi apabila ada aktivitas di ruang pendhapa, ruang akan menjadi aktif. Artinya terdapat aktivitas yang membuat hidup ruang pendhapa. Pemahaman tersebut berlaku juga terhadap pementasan Srimpi Rangga Janur yang dilakukan di pendhapa Ndalem Tedjokusuman yang terpusat di antara keempat saka guru. Dengan demikian keempat saka guru dengan aktivitas para penari menjadi titik 
fokus yang menyatukan seluruh pelaku pertunjukan, termasuk penonton. Dengan demikian bunyi instrumen gamêlan, kehadiran penari yang menarikan Srimpi Rangga Janur membuat penonton hanyut dalam suasana yang memungkinkan penonton berimajinasi menurut persepsi masing-masing.

\section{Variety (Variasi)}

Kata variasi mempunyai beberapa arti yang di antaranya merupakan sebuah tindakan atau hasil perubahan dari keadaan semula, bentuk yang lain, hiasan tambahan. Variasi jika dalam pandangan Jawa dapat disejajarkan dengan wilêd dalam Hasta Sawanda. Wilêd merupakan variasi gerak yang dikembangkan berdasarkan kemampuan bawaan penarinya yang berkaitan dengan ketrampilan, interpretasi, dan improvisasi (Hastuti \& Supriyanti, 2015: 364). Pernyataan tersebut jika diaplikasikan ke tari Srimpi Rangga Janur dapat dilihat dari salah satu gerak, yaitu lèmbèyan. Lèmbèyan merupakan gerak berfokus pada lengan. Gerak tersebut dapat dilakukan berdiri, akan tetapi dalam Srimpi Rangga Janur pada awal bagian dilakukan dengan level yang rendah atau jèngkèng.

\section{Repetition (Pengulangan)}

Sebuah koreografi tidak lepas dari prinsip pengulangan. Pengulangan dilakukan untuk memperjelas sebuah gerak maupun iringan yang pada sebuah tarian. Seperti yang dinyatakan Hayes: Repetition thus helps to clarify, identify, and enrich an esthetic experience (Hayes, 1954: 13). (Pengulangan dengan demikian membantu untuk memperjelas, mengidentifikasi, dan memperkaya pengalaman estetik). Apalagi di dalam koreografi tradisi pada umumnya repetisi menjadi bagian yang ada dalam struktur koreografi. Dari beberapa motif yang diulang dapat diketahui bahwa motif kicat yang terdapat pengulangan paling banyak (8x). Srimpi Rangga Janur yang tergolong Srimpi kuno dikatakan bahwa banyak Srimpi kuno yang menggunakan kicat sebagaimana dinyatakan bahwa:

kalau yang saya tahu memang di semua srimpi-srimpi kuno banyak menggunkaan kicat. Yang banyak adalah kicat lumbungan (ke kanan ijol pojok) dan kicat dari satu garis lurus ajêng-ajêngan lalu membuka menjadi rakit srimpèn lagi seperti Srimpi Rangga Janur (Wawancara dengan Angela Retno, 2020).

Artinya bahwa motif kicat mempunyai banyak variasi yang menyertakan kepala, tangan, kaki, badan, sampur, juga untuk perpindahan menjadikan motif kicat menjadi lebih dinamis. 


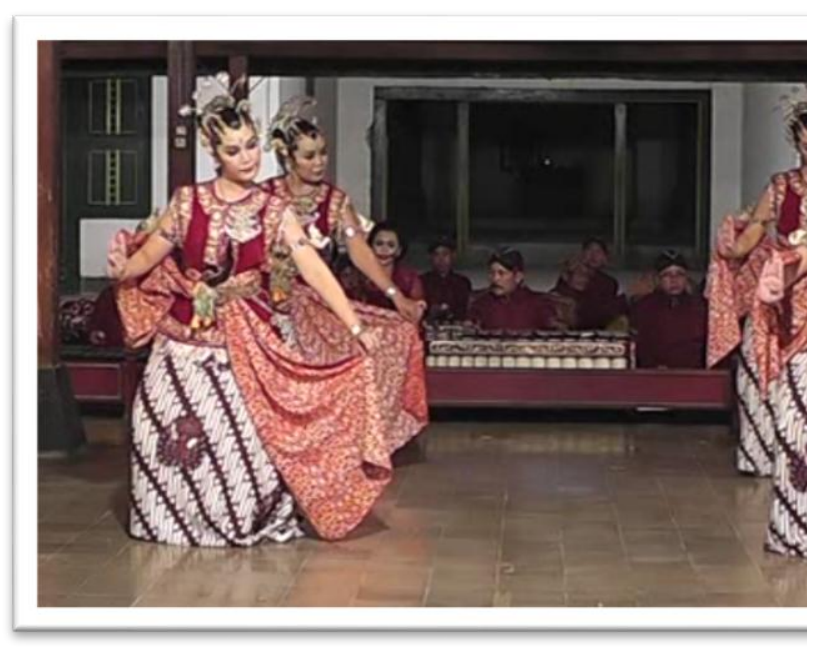

Gambar 6. Motif Kicat merupakan motif yang paling sering diulang

(Dokumentasi: Dinas Kebudayaan DIY, 2014)

\section{Contrast (Berlawanan)}

Kontras seringkali menjelaskan sesuatu yang bertentangan. Di mana kontras juga dibutuhkan untuk menambah suatu keindahan dengan terdapatnya suatu kejutan pada sebuah karya.Tari Srimpi Rangga Janur sebagai bentuk koreografi terdapat motif gerak yang berlawanan atau kontras. Motif gerak yang dilakukan secara pelan dengan iringan yang lambat, pada dasarnya membutuhkan tenaga yang besar. Maksudnya bahwa dalam pola iringan tempo lambat dan gerak yang mengalir lambat, akan tetapi di dalam tubuh terdapat kontras-kontras antar bagian tubuh.

Kontras dapat diketahui juga pada bagian perangan yang menggunakan perang gêndhing. Perang gendhing di mana penari di dalam perang menggunakan keris harus mengikuti irama gendhing. Hal tersebut berlawanan dengan perang dalam pengertian pada umumnya atau perang rukêt. Artinya terjadi kontras antara esensi perang dengan aturan yang dibingkai oleh perang irama. Akan tetapi dalam srimpi menggunakan pola gêndhing dan suasana akan diciptakan lewat gêndhing.

\section{Transition (transisi)}

Transisi merupakan sambungan untuk perpindahan dari gerak satu menuju gerak selanjutnya. Pengertian transisi dapat dijumpai dalam Hasta Sawanda yang disebut pancad. Pancad adalah peralihan gerak satu ke gerak berikutnya dengan penuh perhitungan secara matang agar enak dilakukan dan dilihat, menyangkut sepak terjang atau peralihan dari gerak yang satu ke gerak yang lain (Hastuti \& Supriyanti, 2015: 364). Pada tari putri gaya Yogyakarta transisi antar motif gerak antara lain sêndi cathok, pêndhapan, nyambêr, wêdhi kèngsêr, dan tinting. Transisi dalam tari Srimpi Rangga Janur antara lain: sêndi, pêndhapan, ngancap, nyambêr, nglèrèk cathok udhêt, ongkèk, trisig, kèngsêr, dan tinting.

Transisi yang terdapat dalam iringan tari Srimpi Rangga Janur dapat diketahui pada peralihan antara gêndhing Gonjangsèrèt ke gêndhing Kêtawang Rangga Janur dengan transisi lagon dan bawa. Transisi dari Kêtawang Rangga Janur ke Ayak-ayak dilakukan dengan memperlambat tempo pada empat ketukan terakhir menuju gong. Transisi dari Ayak-ayak ke Srêpêg dilakukan dengan 
mempercepat tempo Ayak-ayak untuk masuk ke Srêpêg. Dari Srêpêg ke Ayak-ayak dengan memperlambat tempo Srêpêg menuju ke Ayakayak. Kemudian yang terakhir terdapat peralihan gendhing dari Ayak-ayak ke gêndhing Lipursari dengan transisi Lagon.

\section{Sequence (urutan)}

Tari Srimpi Rangga Janur merupakan sebuah tarian yang mengisahkan tentang pertandingan Srikandhi dan Larasati. Pertandingan antara keduanya karena Srikandhi membuat sayembara siapa yang bisa melawan dirinya. Pada akhirnya Larasati meminta ijin kepada suaminya atau Arjuna untuk melawan Srikandhi. Walaupun di dalam tarian tersebut tidak diperankan secara jelas untuk tokohnya, karena tari srimpi sangat simbolis. Akan tetapi dalam cerita tersebut tidak ada yang menang dan tidak ada yang kalah. Secara garis besar koreografi tari Srimpi Rangga Janur terdiri dari kapang-kapang majêng, jogèdan, èrèk, pêrangan, bagian ayak-ayak, kemudian kapang-kapang mundur.

Sequence juga dapat disejajarkan dengan konsep mandhêg milir. Konsep ini digunakan untuk membuat pola urutan gerak pada tari Srimpi Rangga Janur. Dalam menyusun sebuah gerak tentunya memerlukan perhitunganperhitungan yang matang. Dengan menggunakan konsep mandhêg milir, tidak mungkin seluruh gerak akan menggunakan mandhêg saja atau milir saja. Namun demikian di dalam setiap motif mengandung konsep mandhêg milir.

\section{Climax (klimaks)}

Ujung atau puncak dari sebuah pertunjukan tari ialah klimaks. Di dalam tari Srimpi Rangga Janur klimaks dapat dilihat pada perang curiga dengan gendhing srepeg. Dinamika dalam gêndhing srêpêg dimulai dari mempercepat tempo ayak-ayak menuju srêpêg. Perang pada tari srimpi tidak dalam bentuk perang rukêt. Artinya perang dilakukan yang terbingkai oleh gêndhing. Perang gendhing di dalam klimaks ini apabila dikaitkan dengan konsep joged Mataram dalam aspek grêgêd yang berarti dinamik atau semangat. Maka untuk menuju klimaks diperlukan dinamika, semangat untuk menuju puncak sajian tari yang memerlukan kerja sama antar penari agar dapat menyatu di dalam membentuk klimaks.

\section{Proportion (proporsi)}

Proporsi dalam hal ini ialah tentang kesesuaian. Hayes menyatakan bahwa: $B y$ definition, "proportion" means the relation of one part to another with respect to magnitude quantity, or degree (Hayes, 1954: 18). (Dengan definisi proporsi, berarti hubungan satu bagian ke bagian lain sehubungan dengan kuantitas besar). Pengertian tersebut dapat dipakai untuk mengetahui proporsi atau kesesuaian gerak, dan pola lantai dalam tari Srimpi Rangga Janur. 


\section{JOGED}

ISSN: $1858-3989$

Proporsi gerak pada tari Srimpi Rangga Janur dapat diketahui dari penggunaan motif gerak dengan sêndi atau transisinya. Proporsi yang terkait dengan pola lantai dalam tari Srimpi Rangga Janur tidak lepas dari tempat pertunjukan yaitu pêndhapa. Pêndhapa dengan empat saka guru yang berada di tengah membingkai desain lantai yang dibentuk. Adanya saka guru yang berbentuk vertikal diharapkan menjadi pertimbangan dalam pemilihan postur tubuh penari. Pemilihan penari srimpi menurut pakar tari putri gaya Yogyakarta bahwa keempat penari itu sama posturnya, dan harus sama gayanya (Wawancara dengan KRT. Pujaningsih, 2020). Dengan konstruksi pêndhapa, proporsi tubuh penari yang sama, gaya penari yang sama maka pada saat membuat desain lantai keempat penari dapat melakukan secara rampak. Oleh karena itu keempat penari harus saling adu rasa dalam menarikan Srimpi.

\section{Balance (keseimbangan)}

Balance atau seimbang berasal dari kata imbang, yaitu keadaan seimbang. Keseimbangan tentunya menjadi salah satu faktor yang mendukung nilai estetis. Bagi penari keseimbangan sangat penting disebabkan kestabilan

gerak akan tetap terjaga. Untuk penari klasik gaya Yogyakarta pathokan-pathokan baku harus dilakukan untuk menjaga keseimbangan.
ESTETIKA TARI SRIMPI RANGGA JANUR PADA MASA SRI SULTAN HAMENGKU BUWONO VIII DI KRATON YOGYAKARTA

Aturan tersebut selalu berkaitan dan tidak dapat dipisahkan. Oleh karena itu kemampuan mengaktifkan cêthik menjadi kunci menjaga keseimbangan anggota badan. Cêthik sebagai pusat keseimbangan harus disadari untuk menjadi bagian dalam aktivitas menari. Hal tersebut dimaksudkan agar setiap gerak menjadi lebih prima dan memiliki power. Seorang penari harus menjaga pola pernafasan untuk menjaga kestabilan power penari. Ketika nafas dapat diatur dengan baik, maka akan menjaga kestabilan sikap badan penari. Posisi mêndhak bagi penari putri menjadi hal yang penting. Oleh karena Srimpi Rangga Janur berdurasi 1 jam maka kestabilan mêndhak harus dijaga. Akan tetapi ada kalanya harus ndudut seperti halnya orang bernafas. Satu waktu menarik nafas kemudian menghembuskan nafas. Ini merupakan strategi dalam menari untuk membagi dan menjaga energi.

Keterkaitan keseimbangan dengan tempat pertunjukan dapat diketahui pada bentuk penyajiannya. Pertunjukan tari tradisi selalu terkait dengan tempat pertunjukan yang identik dengan bangunan untuk pertunjukan tradisi atau bangunan tradisional. Bangunan tersebut ialah pêndhapa yang memiliki konstruksi bangunan pada susunan atas bagian luar menjulang tinggi seperti gunungan. Kemudian pada bagian tengah pêndhapa terdapat penyangga yang disebut saka guru berjumlah empat dan membentuk persegi. 
Keutamaan dari jumlah saka guru adalah empat buah dengan kesan vertikal dan mempunyai suasana pemusatan berada di titik diagonal yang dibentuk oleh keempat titik kedudukan tiap saka guru (Ronald, 2005: 50). Keraton merupakan pancêr atau pusat kebudayaan, maka bangunan di dalam Keraton tidak terlepas dari peran seorang Raja untuk menyelaraskan kehidupan yang ada di dalam dan di luar tembok Keraton.

Pada tari tradisi pertunjukan Srimpi dipergelarkan di pendhapa. Penari masuk pendhapa dari arah kiri pendhapa dengan kapang-kapang. Kemudian menari di tengahtengah saka guru. Setelahnya penari kembali atau kapang-kapang mundur ke arah kanan pêndhapa. Ketiga proses tersebut dapat dikaitkan dengan laku têlu pada kehidupan manusia yaitu lahir, hidup, dan mati. Tata laku tersebut kaitannya dengan sangkan paraning dumadi. Sangkan (asal atau sumber), paraning (tujuan), dan dumadi (hidup). Dengan demikian sangkan paraning dumadi memiliki pengertian asal dan tujuan kehidupan manusia di dalam jagad ramai (dunia) (Achmad, 2019: 17). Pada awal penari memasuki pêndhapa dapat diartikan sebagai manusia lahir atau asal manusia. Saat menari di tengah saka guru dapat diartikan sebagai tujuan hidup manusia, dan kapang-kapang mundur dapat diartikan manusia kembali ke asal mula.
Manusia hidup memiliki nafsu. Nafsu terdiri dari empat macam yaitu: mutma'inah (nafsu keimanan), ammarah (nafsu marah), suwiyyah (nafsu kasih sayang), luwwamah (nafsu kebendaan). Nafsu-nafsu tersebut akan selalu menyertai dalam diri manusia dalam kehidupan duniawi, karena tuntutan kepentingan. Selanjutnya kapang-kapang mundur dapat diartikan manusia kembali ke asalnya. Karena ruh atau nyawa datangnya dari Tuhan, maka paraning (tujuan) manusia sesungguhnya ialah Tuhan (Achmad, 2019: 22). Berdasarkan hal tersebut manusia yang akan kembali kepada Tuhan harus berusaha dengan keras mengendalikan empat nafsu tersebut. Manusia sempurna telah menghayati dan mengerti awal akhir hidupnya. Orang sering menyebut mulih mula mulanira atau meninggal (Astiyanto, 2012: 365)

\section{Harmony (keselarasan)}

Harmoni dimengerti serta digunakan untuk sebuah aransemen dan penciptaan musik. Harmoni pada keselarasan nada merupakan paduan beberapa nada apabila dimainkan bersama dalam satu chord atau keselarasan antara satu chord dengan chord yang lain. Dari pengertian tersebut dapat diadopsi bahwa dari beberapa unsur yang berbeda menjadi satu. Tari Srimpi Rangga Janur yang lahir di lingkungan istana dan ditarikan empat wanita bangsawan, maka dari itu terikat oleh etika wanita 


\section{JOGED}

ISSN: $1858-3989$

bangsawan yang tertutup, halus, runtut, dan teratur. Selain itu tari Srimpi menggunakan properti jêbêng yang dibawakan oleh dhudhuk. Dhudhuk sebagai pêlados yang membawakan properti jêbêng melayani penari Srimpi dapat diibaratkan seorang abdi yang melayani ndaranya. Dengan demikian, tari Srimpi harus dilakukan dengan keselarasan tata laku yang ideal bagi kaum ningrat Jawa. Keselarasan tersebut akan menjadi dasar estetis dalam penyusunan sebuah tari Srimpi. Maka dari itu seluruh gerak tari, irama, ritme gerak, serta gendhing pengiringnya dilakukan dengan lembut, halus, runtut, patut, luruh - jêtmika, penuh dengan tata krama, teratur, terkendali, mbanyu mili, serta tempo yang ajêg (Pudjasworo, 1982: 54). Semua itu menjadikan sebuah pertunjukan srimpi menjadi agung, khidmad, serta dalam. Apalagi penggunaan instrumen kêmanak dalam iringan tari Srimpi Rangga Janur memberikan kesan yang mistis, tenang, agung, khidmad, dan menjadi lebih khusyu'.

Instrumen kêmanak menggunakan dan menghasilkan dua buah nada yang dimainkan selaras dengan vokal. Untuk nada sléndro nada yang dihasilkan ialah nada 5 ( $m a)$ dan nada 6 (nêm), sedangkan untuk laras pélog biasanya nada dipakai ialah nada 7 (pi) dan nada (nêm) (Hendarto, 2006: 47). Bahkan di daerah Afrika tengah bagian barat di antara orang-orang Fang atau Pangwe terdapat pula alat musik yang
ESTETIKA TARI SRIMPI RANGGA JANUR PADA MASA SRI SULTAN HAMENGKU BUWONO VIII DI KRATON YOGYAKARTA

menyerupai kêmanak yang digunakan untuk upacara keagamaan. Nowadays, this same instrument is found in western central Afrika amongst the fang or pangwe people, and agains as accompanying instrument in religious dance (Kunst, 1960: 267). (Sekarang ini alat yang sama ditemukan di Afrika bagian tengah barat di antara suku Fang atau suku Pangwe, dan sekali lagi sebagai alat bantu dalam tarian keagamaan).

Iringan tari Srimpi Rangga Janur dari awal hingga akhir menggunakan laras Sléndro Pathêt Manyura. Di dalam penyajian karawitan dan pergelaran wayang kulit struktur pathêt dimulai dari pathêt nêm, pathêt sanga, dan pathêt manyura. Pathêt nêm sebagai waktu pagi diibaratkan seorang yang baru saja lahir, pathêt sanga sebagai waktu siang diibaratkan seorang yang beranjak dewasa, pathêt manyura sebagai waktu sore diibaratkan seorang yang mulai menua. Tari Srimpi Rangga Janur yang menggunakan pathêt manyura yang identik dengan waktu sore, ibarat umur sudah tua diharapkan sudah mencapai puncak keagamaan yang lebih, sudah tidak bergejolak (mênêp). Hal tersebut selaras dengan makna Rangga Janur. Rangga yang diartikan pangkat tinggi dan Janur dari kata Jannah Nur yang berarti cahaya dari surga. Dengan demikian, dapat dimaknai bahwa Rangga Janur, pathêt manyura, dan instrumen kêmanak membawa ke dalam suasana berdoa. Dari paparan di atas, maka 
melihat pertunjukan tari Srimpi Rangga Janur seakan penonton dibawa ke dalam suasana ngayang batin bukan dalam suasana $n d u d u t$ ati. Ngayang batin bermakna membuat batin terlambung-lambung, melayang-layang menjelajahi alam keindahan yang tanpa batas, tapi rasa hati itu tak dilepas ke luar, ditahan tetap di tempatnya sehingga rasa "mattttt-nya" terjaga di dalam diri. Sedangkan $n d u d u t$ ati adalah konsep seni yang membuat para penikmatnya menahan nafas dengan jantung secara diarik ke luar, dan tanpa sadar menggumamkan "haaaahhhhh" karena ketakjuban. Konsep seni Surakarta dikenal sebagai ndudut ati, sementara di Yogyakarta disebut ngayang batin (http://salimafillah.com/menyambungsultan-agung-bag-9/).

\section{PENUTUP}

Estetika tari Srimpi Rangga Janur pada masa Sri Sultan Hamengku Buwono VIII dapat diketahui dari sepuluh aspek yaitu: unity (keutuhan) jika dikaitkan dengan konsep Jawa tentang sêlirang sêtangkep dan loro-loroning atunggal. Variety (variasi) dapat disejajarkan dengan wilêd dalam Hasta Sawanda. Repetisi (pengulangan) dapat diketahui dari perhitungan beberapa motif yang sering diulang. Contrast (kontras) dapat diketahui dari motif gerak yang terlihat berlawanan. Transtition (transisi) dapat disejajarkan dengan pancad dalam Hasta Sawanda. Sequence (urutan) dapat diketahui dari struktur koreografi dan struktur iringan. Climax (klimaks) dapat diketahui dari struktur koreografi dan struktur gêndhing. Proportion (proporsi) dapat diketahui dari besar kecilnya kuantitas antara gerak, tempat pertunjukan dan penari. Balance (keseimbangan) dapat dikaitkan dengan konsep Jawa tentang sangkan paraning dumadi (mulih mula mulanira). Harmony (selaras) dapat diketahui dari keselarasan dari gendhing pengiring dengan gerak-gerak yang lembut, runtut, patut, luruh - jêtmika, dengan tata krama, teratur, terkendali, mbanyu mili, serta tempo yang ajeg. Dengan demikian analisis konsep estetis tidak hanya dari apa yang dilihat dan apa yang didengar, melainkan juga apa yang menjadi ide dari penciptaan karya tersebut.

\section{DAFTAR SUMBER ACUAN}

\section{A. Manuskrip}

Kagungan Dalem Serat Pasindhen Bedhaya Utawi Srimpi B/S 11. Koleksi Perpustakaan KHP. Kridha Mardawa Kraton Yogyakarta.

Kagungan Dalem Serat Kandha Bedhaya Utawi Srimpi B/S 13. Koleksi Perpustakaan KHP. Kridha Mardawa Kraton Yogyakarta.

\section{B. Sumber Tertulis}

Achmad, Sri Wintala. 2019. Sejarah Agama Jawa. Yogyakarta. Arashka Publisher. 
Astiyanto, Heniy. 2012. Filsafat Jawa Menggali Butir-Butir Kearifan Lokal. Yogyakarta. Warta Pustaka Yogyakarta.

Ensiklopedi Kraton Yogyakarta. 2009. Yogyakarta. Dinas Kebudayaan DIY.

Hayes, Elizabeth. 1954. Dance Composition and Production. New York. The Ronald Press Company.

Hastuti, Bekti Budi \& Supriyanti. 2015. Metode Transformasi Kaidah Estetis Tari Gaya Surakarta. Panggung. Vol. 25, No. 4. (357 - 367).

Hendarto, Sri. 2006. Kemanak, Tinjauan Bentuk dan Fungsinya. Resital Jurnal Ilmiah Seni Pertunjukan. Edisi VII/01. $(40-49)$.

Kunst, J. The Origin Of The Kemanak. KITLV: Bijdragen tot de Taal-, Land-en Volkenkunde 116 (1960), no: 2, Leiden: 263 - 269.

Margana. 2016. Sri Sultan Hamengku Buwono VII dan Kedaton Ambarukmo. Yogyakarta. Dinas Kebudayaan DIY.

Pudjasworo, Bambang. 1982. Analisis Konsep Estetik Koreografi Bedhaya Lambangsari. Skripsi Sarjana S-1. Yogyakarta. Akademi Seni Tari Indonesia.

Ronald, Arya. 2005. Nilai-Nilai Arsitektur Rumah Tradisional Jawa. Yogyakarta. Gadjah Mada University Press.

Safitri, Ilmiawati. 2019. Keraton Yogyakarta Masa Lampau dan Masa Kini: Dinamika Suksesi Raja-Raja Jawa dan Politik Wacana "Raja Perempuan". Indonesian Historical Studies, Vol. 3, No. 1, (44-57).
Sri Sultan Hamengku Buwono X dalam Pidato Penganugerahan Gelar Doctor Honoris Causa Bidang Seni Pertunjukan. 2011. ISI Yogyakarta.

Suharto, Benedictus. 1998. Dance Power: The Concept of Mataya in Yogyakarta Dance. Bandung. Sastrataya Masyarakat Seni Pertunjukan Indonesia.

Suryodiningrat, B.P.A. 1934. Babad Lan Mekaring Joged. Kolf Buning.

Wibowo, Fred (Editor). 1981. Mengenal Tari Klasik Gaya Yogyakarta. Yogyakarta. Dewan Kesenian Provinsi DIY.

Winahyuningsih, M. Heni. 1988. "Analisis Bentuk Tari Bedhaya Sapta”. Skripsi Sarjana S-1. Yogyakarta. Institut Seni Indonesia Yogyakarta.

Zoetmulder, P.J. 1983. Kalangwan Sastra Jawa Kuno Selayang Pandang. Jakarta. Penerbit Djambatan.

\section{Sumber Lisan}

Angela Retno Nooryastuti S. Sn (Guru SMKI Yogyakarta dan Pemucal di Kraton Yogyakarta), 50 MG. Sugiyarti, M. Hum (Dosen Jurusan Tari ISI Yogyakarta), $64^{\text {th }}$ Th. Suharti, S.S.T, SU (KRT. Pujaningsih) Pakar Tari Klasik Gaya Yogyakarta, $70^{\text {th }}$

\section{Webtografi}

1. https://www.kratonjogja.id/rajaraja/9/sri-sultan-hamengku-buwonoviii

2. http://www.salimafillah.com/menyam bung-sultan-agung-bag-9/ 